\title{
Level of Interest in Participating at Sports Extracurricular Activity of High School Students
}

\author{
$1^{\text {st }}$ Rifan Abdurrohman \\ Physical Education, Health and \\ Recreation \\ State University of Malang \\ Malang, Indonesia \\ Abdur.affan@gmail.com
}

\author{
$2^{\text {nd }}$ Tatok Sugiarto \\ Physical Education, Health and \\ Recreation \\ State University of Malang \\ Malang, Indonesia \\ Tatok.sugiarto.fik@gmail.com
}

\author{
$3^{\text {rd }}$ Febrita Paulina Heynoek \\ Physical Education, Health and \\ Recreation \\ State University of Malang \\ Malang, Indonesia \\ febrita.paulina.fik@um.ac.id
}

\begin{abstract}
The purpose of this study was to determine the participants' interest in extracurricular activities for volleyball at Madrasah Aliyah Negeri (MAN) Kota Batu. The research design was a descriptive research design. The method used is a survey method. The research subjects were 24 participants consisting of male participants for volleyball extracurricular activities reaching 14 participants and female participants in volleyball extracurricular activities reaching 10 participants. This research is included in survey research. Based on the research results, the interest of volleyball extracurricular members at Madrasah Aliyah Negeri (MAN) Batu City is in the very good category.
\end{abstract}

Keywords-interests, extracurricular, volleyball.

\section{INTRODUCTION}

Education is a process to influence students in adjusting themselves as best as possible to the community environment, thus the community increasingly realizes that the importance of providing education to their children from an early age. There are many ways to provide education to children, namely formally and non-formally. Education in the school environment is one of the means of formal education that has a lot of support and assistance from teaching teachers and positive activities at school. Education in schools is said to be formal because teaching and learning activities in the classroom are carried out in a planned and organized manner, with the aim of producing positive changes in children through learning efforts. In addition to formal education, there is non-formal education which is an activity to develop talents and interests to support the achievement of educational activities, for example by participating in extracurricular activities.

Sports extracurricular activities are one of the places to channel the interests and talents of a student in the field of sports and also as a means of coaching and achievement if followed and pursued properly. Through sports extracurricular activities, students are expected to achieve impressive achievements in school. In addition, students can highlight their potential that has not been seen during teaching and learning activities in class. Madrasah Aliyah Negeri (MAN) Kota Batu is one of the schools that provides sports extracurricular activities. There are various kinds of sports extracurricular activities provided, including futsal, volleyball, basketball, badminton, table tennis, pencak silat, and karate. From the results of observations made by researchers regarding extracurricular names, the number of extracurricular participants, active and inactive sports at Madrasah Aliyah Negeri (MAN) Kota Batu, volleyball extracurricular activities have the lowest number of participants in interest.

Interest is the main motivational tool that can arouse students' enthusiasm for learning within a certain period of time"[1]. The interests of each volleyball extracurricular participant are certainly different and are influenced by several factors. The factors that influence the emergence of interest can be broadly grouped into two, namely originating from the individual itself and originating from outside, which includes the family, school, and community environment. Understanding each individual's interest based on existing characteristics needs to be done in order to determine the participant's life. Each participant has different interest characteristics according to their respective characteristics. In addition, the characteristics of growing interest also depend on the environment and from the participants themselves so that each participant has different interest characteristics. With the existing interest in each individual, it will facilitate and accelerate the development of interest. In addition, increasing interest can be done by motivating participants by each coach, parent, and the closest person to the volleyball extracurricular sports participant.

Volleyball is a team game that is quite popular in the world with the rules of the game bouncing the ball over the net at a certain height using some basic volleyball techniques to drop the ball on the opponent's field. "Volleyball game is one of the most successful, popular, competitive and fun sports in the world" [2]. The game of volleyball has several basic techniques that must be mastered and understood in order to play it. The basic techniques in volleyball include serving, passing, smash, and block. For people who have never played volleyball, doing basic volleyball techniques is a difficult activity to do. If the interest of participants in volleyball extracurricular activities is not good or cannot be regular, it will be difficult to improve skills and teamwork in playing.

In a study, there are several methods used, ranging from development, experimentation, correlation, classroom action research, to surveys. The choice of survey research method is used to solve problems with a large number of participants and the problems that exist in the study. Jogiyanto (2013: 3) argues that "a survey (survey) or opinion poll or complete self-administered survey is a method of collecting 
primary data by giving questions to respondents in writing". In addition, a survey can also be interpreted as a form of research or exploration carried out by distributing questionnaires or interviews to obtain information based on existing facts. Surveys are carried out with the sole purpose of giving a picture of a problem. Each study has different objectives according to the problems found in a study.

Based on the results of observations and interviews conducted by researchers at Madrasah Aliyah Negeri (MAN) Kota Batu, there has never been a survey of interest in extracurricular activities for volleyball sports. This needs to be done to determine the cause of the irregularity of the participants in participating in extracurricular activities for volleyball at Madrasah Aliyah Negeri (MAN) Batu City. Based on the background of the problems described, the researchers conducted a study entitled "Survey of Volleyball Extracurricular Interest in Madrasah Aliyah Negeri (MAN) Batu City". The purpose of this study was to determine the interests of extracurricular volleyball participants at Madrasah Aliyah Negeri (MAN) Kota Batu.

\section{METHOD}

This research is a descriptive quantitative research with a survey method. This researcher describes each indicator and variable from the school according to the problems that exist in the research area, namely the interest of participants in volleyball extracurricular activities. This research was conducted in March with the subjects of this study were extracurricular volleyball participants at Madrasah Aliyah Negeri (MAN) Batu City with a total of 14 (fourteen) male and 10 (ten) female participants.

The instrument used in this study was a non-test in the form of a questionnaire using a Likert scale questionnaire, observation, and documentation. The answer to each instrument item using the Likert scale has a gradation from very positive to very negative, which can be in the form of words a) very good, b) good, c) not good, d) very bad. For the purposes of quantitative analysis, the answer can be given a score, for example a) very good with a score of $4, b$ ) good with a score of $3, \mathrm{c})$ not good with a score of $2, \mathrm{~d}$ ) not good with a score of 1 . The researcher uses 4 answer gradations so that respondents are clearer whether the extracurricular participants' interests are very good, good, not good, or not good. The type of Likert scale used in this study is multiple choice because according to the researcher using multiple choice is easier to understand. This instrument will be tested first for its validity and reliability so that this instrument is suitable to be used as an instrument. Direct observations are also made to strengthen the data taken in a study. Observations were made by observing participants in extracurricular activities for volleyball at Madrasah Aliyah Negeri (MAN) Batu City. In collecting the research data, the researcher took several steps, including: 1) the preparation stage, 2) the implementation stage, 3 ) the results reporting stage.

\section{RESULT}

The instrument validity test data shows that all questions have a correlation value (product moment) greater than the $r$ table value of 0.404 . While the instrument reliability test in this research questionnaire is $r$ count $0.854>0.404 \mathrm{r}$ table. The data for the interest test used a questionnaire on the volleyball extracurricular members at Madrasah Aliyah Negeri (MAN) Batu City with a total of 24 participants.

Table 1.Data Analysis of All Interest Variables Participants in Volleyball Extracurricular Sports at Madrasah Aliyah Negeri (MAN) Kota Batu

\begin{tabular}{llllcl}
\hline No & Variabel & f & N & Klasifikasi & Persentase(P) \\
\hline 1 & Feeling & 686 & 768 & $89 \%$ & Very well \\
2 & Attention & 327 & 384 & $85 \%$ & Very well \\
3 & Needs & 1540 & 1728 & $89 \%$ & Very well \\
& Ammount & $\mathbf{2 5 5 3}$ & $\mathbf{2 8 8 0}$ & $\mathbf{8 8 \%}$ & Very well \\
\hline
\end{tabular}

The average calculation can be seen from the results of data analysis of all variables that the percentage of participants' interest in volleyball extracurricular activities by $91 \%$ is included in the very good category. The feeling variable is $89 \%$, the attention variable is $85 \%$, and the needs variable is $89 \%$. Based on the results of data analysis that has been described, the interest of extracurricular volleyball sports participants at Madrasah Aliyah Negeri (MAN) Batu City is included in the excellent category.

\section{DISCUSSION}

Basically, the interest of an individual is not carried from birth, but is obtained from everyday life which is influenced by the characteristics of each volleyball extracurricular participant at Madrasah Aliyah Negeri (MAN) Batu City. Argue that "simple interest can be interpreted as a tendency to pay attention and act on people, activities or situations that are the object of that interest with feelings of pleasure"[3]. In this case, the object is the interest in extracurricular activities for volleyball at Madrasah Aliyah Negeri (MAN) Batu City. Interest is very much influenced by the factors that exist in each participant. The factors that influence a person's interest consist of internal factors and external factors. These two factors are interrelated in determining one's interests. The factors contained in these internal factors and external factors consist of feelings, concerns, and needs.

Measuring interest in extracurricular activities for volleyball at Madrasah Aliyah Negeri (MAN) Batu City is something that has never been done. The results of the analysis that have been presented show that the interest of the volleyball extracurricular members at Madrasah Aliyah Negeri (MAN) Batu City shows a very good category. Based on the results of the research, the data that has been obtained from the variables of feelings, variables of attention, and variables of needs have been percentage. The feeling variable of the extracurricular sports participants at Madrasah Aliyah Negeri (MAN) Batu City was $89 \%$ and the variable of attention of the volleyball extracurricular participants at Madrasah Aliyah Negeri (MAN) Batu City was $85 \%$. Meanwhile, the variable needs of volleyball extracurricular members at Madrasah Aliyah Negeri (MAN) Batu City is $89 \%$. Thus, the interest of volleyball extracurricular participants at State Junior High Schools in Kecamatan Tarik, 
Sidoarjo Regency is in the very good category with a percentage of $88 \%$.

Based on the results of the data, the variable feeling of the volleyball extracurricular members at Madrasah Aliyah Negeri (MAN) Batu City is categorized as very good with a percentage of $89 \%$. The high feelings of the participants to take part in extracurricular activities for volleyball were based on the desire to be able to play volleyball. In addition, high willingness also makes someone pay more attention to something they like and is supported by the existence of interesting things in volleyball extracurricular activities. "feeling is a function of the soul to be able to consider and measure something according to pleasure and not happy" [4]. Feelings can be influenced by several indicators, while indicators that can affect the feeling variables of the participants are desire, interest, liking, and willingness. Extracurricular participants will have better interests if all of these factors are well owned or developed. With a good feeling of interest, the participants will take part in extracurricular activities regularly.

Based on the data, the attention variable of volleyball extracurricular participants at Madrasah Aliyah Negeri (MAN) Batu City is included in the very good category with a percentage of $85 \%$. In this research, the attention can be in the form of motivation and talents. Motivation to become a professional volleyball player and as a way to achieve achievements is very influential on the high level of one's attention. In addition, participants assumed that the talents of each participant needed to be developed so that participants paid more attention to extracurricular activities for school volleyball. Interests and talents are often considered as an inseparable unit, so that increasing one's interest can use the talents of existing talents. The indicators that affect the attention variable are motivation and talent. States that "attention is the ability and process of thinking through the five senses which is carried out directly on certain objects that involve thinking and feeling processes" [5]. In the variable, attention is mostly influenced by several internal factors that affect an interest.

Based on the results of the analysis from filling out the research questionnaire regarding the variable of needs, data were obtained by $89 \%$ which were included in the good category. These results indicate that the volleyball extracurricular participants at Madrasah Aliyah Negeri (MAN) Batu City have a good need variable. State that "as a psychophysical creature, humans have physical and psychological needs, and as individual and social beings humans have individual needs and social needs" [6]. Each participant has different needs. The variables of these needs consist of physiological needs, physical fitness needs, the need to get something, and prescription facilities which cause participants to pay more attention to volleyball extracurricular activities. Meeting or increasing one's needs can be used as a way to increase interest in participants in volleyball extracurricular activities. If the attention variable is lacking, it can cause the interest of the volleyball extracurricular participants to decrease. Indicators that affect the need variable are physiology, physical fitness, getting something and infrastructure.

Interest is a feeling of preference and attachment to something or activity without being asked, but basically acceptance of a relationship between oneself and something outside oneself [7]. Each participant has different interests according to their respective characteristics. Internal factors and external factors are one that causes differences in interest in each volleyball extracurricular participant. Therefore, the trainer needs to understand the characteristics of each participant in order to create new interests or increase existing ones. Based on this statement, it can be concluded that the interest of volleyball extracurricular participants at State Junior High Schools in Tarik District, Sidoarjo Regency is in the very good category.

\section{CONCLUSION}

Based on the research results, the interest of volleyball extracurricular members at Madrasah Aliyah Negeri (MAN) Batu City is in the very good category. The variable of participants' feelings towards volleyball extracurricular activities at Madrasah Aliyah Negeri (MAN) Batu City was $89 \%$ and was categorized as very good. The participant's attention variable to volleyball extracurricular activities was in $85 \%$ and it was categorized as very good. The participant's need for extracurricular activities for volleyball was $89 \%$ and it was categorized as good. From the results of data analysis on feelings, attention, and needs of volleyball extracurricular participants, it can be concluded that the interest of volleyball extracurricular participants at Madrasah Aliyah Negeri (MAN) Batu City is $88 \%$ and categorized as very good.

\section{REFERENCES}

[1] S. B. Dianmarah, Psikologi Belajar. Jakarta: Rieneka Cipta, 2008.

[2] PBVSI, Peraturan Permainan Bolavoli. Jakarta, 2015.

[3] A. R. Shaleh and M. A. Wahab, Psikologi Suatu Pengantar. Jakarta: Kencana, 2004.

[4] A. Sujanto, Psikologi Umum. Jakarrta: Bumi Aksara, 2009.

[5] Komarudin, Psikologi Olahraga. Bandung: PT REMAJA ROSDAKARYA, 2015.

[6] H. Sunarto, Hartono, and B. Agung, Perkembangan Peserta Didik. Jakarta: Rineka Cipta, 2013.

[7] Slameto, Belajar dan Faktor-Faktor Yang Mempengaruhinya. Jakarrta: PT Rineka Cipta, 2003. 